\title{
Kegiatan Press Tour Sebagai Strategi Media Relations
}

\author{
Titin Suhartini' ${ }^{1}$ Kadek Maria Elvira ${ }^{2}$ \\ 1,2Universitas BSI, Indonesia, email: titin.ttr@bsi.ac.id
}

\begin{abstract}
ABSTRAK
Penelitian ini mendeskripsikan Strategi Media Relations PT. Pos Indonesia dalam meningkatkan citra positif melalui Kegiatan Press Tour. Metode penelitian yang digunakan adalah metode penelitian kualitatif. Teknik pengumpulan data dilakukan melalui studi kepustakaan, dan wawancara mendalam. Hasil dari penelitian ini menunjukan bahwa strategi yang dilakukan dalam kegiatan media relations khususnya kegiatan press tour berjalan dengan baik dan sesuai dengan tujuan perusahaan, terbukti dengan adanya publikasi yang dilakukan oleh para media yang hadir. Dalam strategi pelayanan yang diberikan pada media sangat baik seperti ontime pada saat kegiatan, memberikan fasilitas yang dibutuhkan, dan memberikan kebebasan pada media dalam bertanya dan meliput. Dalam Strategi yang dilakukan dengan kerja sama yang baik dalam menyediakan bahan informasi sangat baik yaitu memberikan release pada media dengan tujuan agar media yang hadir sudah mengerti tentang pembahasan dalam kegiatan press tour.
\end{abstract}

Kata Kunci: Strategi Media Relations, Public Relations, Media Relations

\begin{abstract}
This research describes Media Relations Strategy PT. Pos Indonesia in improving positive image through Activity Press Tour. The research method used is qualitative research method. Data collection techniques were conducted through literature studies, and in-depth interviews. The results of this study indicate that the strategies undertaken in media relations activities, especially the press tour activities run well and in accordance with corporate objectives, as evidenced by the publication conducted by the media present. In the service strategy given to the media very well like ontime at the time of activities, provide the required facilities, and give freedom to the media in asking and covering. In Strategy that is done with good cooperation in providing information material is very good that is giving release to media with aim to media present that already understand about discussion in activity of press tour.
\end{abstract}

Keywords: Media Relations Strategy, Public Relations, Media Relations

Diterima: 14 Jan 2019; Direvisi: 20 Mar 2019; Diterbitkan: 15 April 2019

\section{PENDAHULUAN}

Kegiatan press tour didalam PT. Pos Indonesia yang dilakukan oleh praktisi public relations (PR) tidak mengunjungi tempat wisata, namun press tour yang dilakukan oleh praktisi PR merupakan kegiatan yang mengundang para media untuk memberikan informasi yang terbaru akan PT. Pos Indonesia.

Press tour merupakan cara untuk PR mendekatkan diri dengan media terutama para jurnalis. Press tour rutin diselenggarakan disetiap tahun tetapi terkadang dua kali dalam setahun, tergantung adanya perubahan yang ingin ditunjukkan pada media. Press tour akan diselenggarakan jika memang adanya suatu perubahan dan perkembangan yang baru.

Kegiatan press tour PT. Pos Indonesia tidak sekedar jalan - jalan saja melainkan adanya pesan yang ditunjukkan pada media sehingga media dapat memberitakan informasi yang terbaru mengenai perusahaan. Didalam kegiatan press tour adanya suatu strategi yang membuat kegiatan tersebut berjalan dengan lancar sesuai dengan harapan perusahaan. Strategi yang membuat para media merasa nyaman dan dapat meningkatkan citra perusahaan.

Tujuan dari press tour PT. Pos Indonesia adalah salah satu bagian dari media relations dan menyampaikan informasi atau perkembangan terbaru mengenai perusahaan. Didalam kegiatan press tour adanya penyampaian informasi yang terbaru akan perusahaan dan diberitahukan kepada media dengan tujuan release akan dimuat oleh media sehingga sampai pada sasaran utama yaitu publik. Dengan adanya penyebaran informasi 
yang dilakukan oleh pihak media dapat meningkatkan kepercayaan publik terhadap PT. Pos Indonesia.

Pada tahun 2016 PT. Pos Indonesia Bandung menyelenggarakan kegiatan Press Tour Launching Kantor Processing Center dan dihadiri oleh 35 media, media tersebut merupakan media cetak, elektronik maupun online tetapi media terbanyak yang hadir adalah media cetak dan media online. Kegiatan press tour ini diselenggarakan di Jalan Soekarno Hatta No.558 bertempat di kantor Processing Center Pos Indonesia yang berada di Kota Bandung. Dari kegiatan press tour ini adanya suatu perubahan dari kantor Processing Center Pos Indonesia dalam peningkatan standarisasi pos menjadi standar internasional. Dari hasil benchmark yang dilakukan oleh tim operasi dan bisnis dimana kantor Processing Center Indonesia yang berada di Kota Bandung sebagai pusat jasa pengiriman logistik maka harus adanya suatu perubahan dengan standar internasional.

Strategi dari media relations PT. Pos Indonesia Bandung adalah mengkombinasikan kegiatan media relations secara formal dan informal, walaupun PR Pos Indonesia lebih menyukai informal karena dianggap lebih bisa mengakrabkan dari pihak PR dan para media, selain itu PR dan pihak media mengenal baik satu sama lain secara pribadi dan tentunya memiliki contact person.

Kegiatan media relations akan membawa efek yang sangat besar apabila dilakukan dengan menggunakan strategi yang tepat. Kegiatan media relations PT. Pos Indonesia adalah suatu kegiatan yang dibuat oleh perusahaan dan melibatkan pihak dari media massa. Kegiatan media relations PT. Pos Indonesia terdapat dua kegiatan diantaranya kegiatan formal dan informal. Didalam kegiatan media relations formal meliputi media visit, press release, press tour dan kegiatan media relations informal diantaranya kuliner bersama, olahraga bersama, dll.

PT. Pos Indonesia merupakan sebuah badan usaha milik negara (BUMN) Indonesia yang bergerak di bidang jasa pelayanan dan pengiriman pos. Sebagai jasa pelayanan dan pengiriman yang sudah lama ada di Indonesia dan sudah dikenal oleh publiknya tidak membuat PT. Pos Indonesia merasa tenang dikarenakan saat ini banyaknya jasa pelayanan atau pengiriman lain yang ada di Indonesia dan tentunya membuat PT. Pos Indonesia membuat berbagai strategi, salah satunya yaitu strategi media relations yang dapat meningkatkan atau membantu terciptanya citra positif dari publiknya. Salah satu strategi yang dibuat oleh praktisi PR, antara lain kegiatan media relations. Adanya praktisi PR di dalam PT. Pos Indonesia yang bertugas dalam meningkatkan, memelihara, dan menciptakan citra yang positif dimata publiknya.

Penelitian ini penting dilakukan untuk mengetahui bagaimana strategi media relations yang dilakukan oleh PR PT. Pos Indonesia melalui kegiatan press tour dalam menciptakan citra positif. Sehingga penelitian ini bertujuan mengkaji dampak positif press tour sebagai strategi media relations.

\section{KAJIAN TEORETIK Press tour}

Press tour adalah acara yang diselenggarakan oleh suatu organisasi untuk memberikan kesempatan wartawan mengetahui kondisi, aktivitas serta permasalahan yang mungkin dihadapi oleh organisasi. Press tour pada umumnya merupakan kegiatan yang direncanakan oleh organisasi atau perusahaan untuk meningkatkan hubungan baik dengan wartawan.

Aceng Abdullah menjelaskan Press Tour adalah kegiatan mengajak kalangan wartawan untuk berkunjung ke suatu lokasi, baik yang berada di lingkungan maupun ketempat atau lokasi yang memiliki kaitan erat dengan kiprah lembaga tersebut.

Onong Uchjana Effendy menjelaskan Press Tour adalah perjalanan rombongan wartawan yang diatur oleh kepala hubungan masyarakat suatu instansi atau lembaga untuk meliput suatu peristiwa tertentu. Perencanaan acara press tour :

1. Menentukan tujuan press tour

2. Menentukan media mana yang akan dilibatkan disesuaikan dengan audiens dan momen press tour itu sendiri

3. Menentukan tanggal acara, berapa lama perjalanan dan kegiatan itu berlangsung, menentukan alat transportasi, akomodasi, uang saku, obyek yang akan dkunjungi

4. Menentukan pihak ketiga yang akan berkerjasama

5. Menentukan biaya/anggaran keseluruhan acara tersebut 
6. Menyediakan tiket perjalanan, susunan acara, denah tempat, route perjalanan, nama pemandu dan sebagainya.

Pelaksanaan acara press tour :

1. Menghubungi media mana yang akan diundang seminggu sebelum acara berlangsung

2. Memandu perjalanan dengan mengkaitkan selalu pada tujuan press tour itu sendiri

3. Melakukan perjalanan dan melayani kepentingan wartawan mulai dari akomodasi,

4. Melayani wartawan dengan ketulusan dan kejujuran akan sangat dihargai

5. Melakukan evaluasi dengan memperhatikan isi tulisan atau publikasi medianya.

\section{Media Relations}

Yosal Iriantara mengartikan media relations merupakan bagian dari public relations eksternal yang membina dan mengembangkan hubungan baik dengan media massa sebagai sarana komunikasi antara organisasi dengan publik untuk mencapai tujuan organisasi. (Saputra\&Nasrullah, 2011).

Fungsi-fungsi inilah yang menempatkan media relations sebagai bagian dari aktivitas public relations. Bahkan John Vivian memberikan perhatian khusus pada posisi media relations. Bahwa public relations memiliki tiga tanggung jawab fungsional.

1. Relasi Eksternal. Komunikasi yang dijalin dengan kelompok orang- orang di luar perusahaan, konsumen, dealer, supplier, tokoh masyarakat, orang-orang pemerintahan.

2. Relasi Internal. Komunikasi yang dikembangkan untuk menjaga hubungan optimal antara karyawan, manajer, serikat pekerja, pemegang saham, dan kelompok internal lainnya.

3. Relasi Media. Komunikasi yang dilakukan perusahaan dengan media massa. (Saputra\&Nasrullah, 2011).

\section{Strategi Media Relations}

Soleh Sumirat dan Elvinaro Ardianto memberikan rincian yang sangat jelas tentang strategi komunikasi Public Relations dengan Media. Strategi komunikasi Public Relations dengan Media tersebut adalah :

\section{By Serving the media}

Strategi ini adalah strategi dengan memberikan pelayanan kepada media. Pada tataran ini, seorang Public Relations dituntut untuk memberikan pelayanan kepada media dengan cara selalu siap dalam memberikan pelayanannya kepada media massa, sesuai yang dibutuhkan oleh media massa tersebut.

\section{By Establishing a reputations for reliability}

Strategi by establishing a reputations for reliability adalah strategi yang dilakukan oleh Public Relations sebagai upaya untuk menegakkan reputasi perusahaan supaya perusahaan tersebut tetap dapat dipercaya. Untuk membangun kepercayaan masyarakat, perusahaan atau organisasi tidak bisa hanya mengandalkan promosi atau memasang iklan di media massa.

\section{By supplying good copy}

Strategi by supplying good copy adalah strategi dapat memasok naskah informasi yang baik. Naskah informasi dapat dibuat dalam bentuk artikel yang berupa opini atau pendapat tentang suatu permasalahan. Naskah infromasi yang baik bisa diberikan berdasarkan datadata yang sebenarnya.

\section{By cooperations in providing material}

Strategi by cooperations in providing material adalah strategi yang dilakukan dengan kerja sama yang baik dalam menyediakan bahan informasi.

\section{By providing verification facilities}

Seorang Public Relations juga harus memikirkan fasilitas yang harus disediakan bagi pekerja-pekerja media. Tujuannya adalah pekerja media merasa nyaman dalam bekerja, yaitu ketika mereka melakukan liputan terhadap perusahaan tempat Public Relations itu berada.

6. By building personal relationship with the media

Strategi ini merupakan strategi yang dilakukan dengan membangun hubungan secara personal antara Public Relations dengan media massa. Hubungan personal yang baik antara Public Relations dengan pekerja media diharapkan dapat digunakan sebagai dasar untuk saling menghormati antarprofesi masing-masing (Darmastuti, 2012).

\section{Public Relations}

Menurut Byron Christian, PR merupakan suatu usaha sadar memotivasi 
terutama melalui komunikasi agar orangorang terpengaruh, timbul pikiran yang sehat terhadap suatu organisasi, memberi rasa hormat, mendukung dan memberi kesadaran dengan berbagai cobaan dan masalah. (Ardianto, 2014)

Semua kemampuan yang dimiliki oleh Public Relations, seyogyanya dituangkan ke dalam tugas atau fungsinya. International Public Relations Associatios IPRA menegaskan dengan berbagai kemampuan tersebut, diharapkan Public Relations dapat memposisikan dirinya sebagai konseling, seorang analisis realitas, ahli riset pendapat dan sikap publik. PR juga piawai dalam membina komunikasi dua arah, mencegah konflik, meningkatkan rasa percaya dan tanggung jawab, memperbaiki dan mempertahankan hubungan, memasyarakatkan produk atau jasa dan menciptakan jati diri institusi. Segudang pekerjaan sebagai tanggung jawab harus dilakukan secara baik agar mendapatkan hasil yang efisien dan efektif. (Hidayat, 2014)

\section{Citra}

Frank Jefkins mengatakan bahwa citra adalah kesan seseorang atau individu tentang sesuatu yang muncul sebagai hasil dari pengetahuan dan pengalamannya. Citra adalah kesan yang diperoleh berdasarkan pengetahuan dan pengertian seseorang tentang fakta-fakta atau kenyataan. (Ardianto, 2014)

Jenis-jenis citra; Pertama, citra bayangan (mirror image) adalah citra yang melekat pada orang atau anggota-anggota organisasi, dan citra yang dianut oleh orang dalam mengenai pandangan luar terhadap organisasinya. Kedua, citra yang berlaku (current imgae) adalah kebalikan dari citra bayangan atau pandangan yang dianut oleh pihak-pihak luar mengenai suatu organisasi. Ketiga, citra yang diharapkan (wish image) adalah suatu citra yang diinginkan oleh pihak manajemen. Citra yang diharapkan itu lebih baik atau lebih menyenangkan daripada citra yang ada. Keempat, citra perusahaan atau citra lembaga (corporate image) adalah citra dari suatu organisasi secara keseluruhan. Kelima, Citra majemuk (multiple image). (Ardianto, 2014)

\section{Citra Perusahaan}

Menurut Siswanto Sutojo, citra sebagai pancaran atau reproduksi jati diri atau bentuk orang perorangan, benda atau organisasi. Citra perusahaan menjadi salah satu pegangan bagi banyak orang dalam mengambil berbagai macam keputusan penting. Contohnya membeli barang atau jasa yang dihasilkan perusahaan (konsumen), berlangganan (pelanggan), merekomendasikan kepada orang lain. (Ardianto, 2014)

Menurut Siswanto Sutojo, citra perusahaan yang baik dan kuat mempunyai manfaat; Pertama, daya saing jangka menengah dan panjang yang mantap. Kedua, menjadi perisai selama masa krisis. Ketiga, mejadi daya tarik eksekutif handal. Keempat, meningkatkan efektivitas strategi pemasaran. Kelima, strategi hemat biaya operasional karena citranya baik. (Ardianto, 2014)

\section{Teori Media (Medium Theory)}

Marshall McLuhan yang menyatakan bahwa medium is the message atau media adalah pesan. Teori media (medium theory) adalah tentang bagaimana media dan proses komunikasi mempengaruhi persepsi manusia, perasaan, dan emosi. Diyakini bahwa media yang dipilih untuk menyampaikan pesan adalah sama pentingnya dari pesan itu sendiri.

Dalam prespektif teori ini, bukan pesan yang mempengaruhi kesadaran kita tetapi medium. Medium lah yang lebih besar mempengaruhi bawah sadar kita. Medium membentuk pesan, bukan sebaliknya. Artinya media elektronik telah mengubah masyarakat secara radikal. Masyarakat sangat bergantung pada teknologi yang menggunakan media dan bahwa ketertiban sosial suatu masyarakat didasarkan pada kemampuannya untuk menghadapi teknologi tersebut. Di sisi lain, media sebagai bagian dari pesan apapun yang dikirimkan, memiliki dampak bagi setiap individu dan masyarakat.

\section{METODE PENELITIAN}

Pada penelitian ini menggunakan metode penelitian kualitatif. Dalam penelitian kualitatif, seorang peneliti menjadi instrumen kunci dan peneliti terlibat sepenuhnya dalam kegiatan informan kunci yaitu praktisi public relations PT. Pos Indonesia yang menjadi subjek penelitian dan sumber informasi. Dalam penelitian kualitatif metode yang 
biasanya dimanfaatkan adalah wawancara pengamatan, dan pemanfaatan dokumen.

Menurut Danim, penelitian kualitatif berangkat dari ilmu-ilmu perilaku dan ilmuilmu sosial. Esensinya adalah sebagai sebuah metode pemahaman atas interaksinya dengan lingkungan. Peneliti kualitatif percaya bahwa kebenaran adalah dinamis dan dapat ditemukan hanya melalui penelaahan terhadap orang-orang dalam interaksinya dengan situasi sosial kesejahteraan. (Ardianto, 2014)

Peneliti melakukan penelitian ini dengan kondisi yang alamiah dan peneliti berperan sebagai instrumen kunci dengan bantuan informan kunci dalam mengumpulkan data - data yang ada di lapangan. Peneliti menggunakan metode kualitatif untuk menggali informasi sedalam mungkin yakni dengan melakukan wawancara langsung dengan para narasumber sehingga mendapatkan jawaban yang alamiah atau benar-benar murni tanpa rekayasa.

Paradigma yang digunakan didalam penelitian ini adalah paradigma Konstruktivisme. Konstruktivisme menegaskan bahwa pengetahuan tidak lepas dari subjek yang sedang belajar mengerti. Konstruktivisme adalah salah satu filsafat pengetahuan yang menekankan bahwa pengetahuan kita adalah konstruksi (bentukan) kita sendiri. Paradigma ini memandang ilmu sosial sebagai analisis sistematis terhadap socially meaningful action melalui pengamatan langsung dan terperinci terhadap pelaku sosial yang bersangkutan menciptakan dan memelihara atau mengelola dunia sosial mereka. Dalam penelitian ini pengamatan yang dilakukan secara langsung terhadap subjek penelitian yaitu Informan dalam penelitian ini adalah praktisi PR yang berada di PT. Pos Indonesia dan objek penelitian yaitu strategi media relations melalui kegiatan press tour, untuk mendapatkan data yang akan disusun melalui ilmu pengetahuan atau teori-teori yang sesuai dengan realitas hasil penelitian dilapangan.

Informan dalam penelitian ini terdiri dari dua orang, ke dua informan tersebut adalah subjek dalam penelitian ini yang memberikan informasi melalui wawancara yang peneliti lakukan sebagai bahan untuk memperoleh data penelitian. Informan tersebut adalah Riyan Hardiyana sebagai FP Dukungan Eksternal dan FP Dukungan Pers
PT. Pos Indonesia. Informan disini terdiri dari informan kunci dan informan tambahan.

\section{HASIL PENELITIAN DAN PEMBAHASAN Strategi media relations PT. Pos Indonesia melalui kegiatan press tour}

Strategi media relations PT. Pos Indonesia melalui kegiatan press tour dalam menciptakan citra positif adalah dengan memberikan pelayanan yang baik kepada media, strategi yang dilakukan dengan kerja sama yang baik dalam menyediakan bahan informasi dan setelah kegiatan press tour dilakukan PR PT. Pos Indonesia melakukan penilaian agar mengetahui sejauh mana keberhasilan dari kegiatan yang telah dilakukan.

Menurut Jefkins ada beberapa hal yang harus diperhatikan praktisi atau institusi PR dalam menyelenggarakan media relations adalah memahami dan melayani media dengan memahami bagaimana cara kerja media serta siapa khalayak dari media itu. Seorang PR juga harus melayani media. Maksudnya, seorang PR harus menyediakan informasi yang dibutuhkan oleh media. (Darmastuti, 2012)

Berdasarkan data yang peneliti temukan dilapangan, ada beberapa cara yang dilakukan dalam membuat strategi pelayanan agar media yang hadir merasa nyaman. PR PT. Pos Indonesia memahami media seperti yang dilakukan dalam strategi pelayanan yaitu tepat waktu dalam pelaksanaan kegiatan press tour, dimana PR PT. Pos Indonesia mengetahui bahwa para media memiliki banyak agenda lainnya. Dalam melayani media di kegiatan press tour, PR PT. Pos Indonesia pun meyediakan informasi yang dibutuhkan oleh media seperti hal nya release yang diberikan untuk para media yang hadir dan juga para media diperbolehkan secara bebas dalam meliput dan wawancara dengan sumber informasi terkait.

Menurut Ardianto, seorang PR juga harus memikirkan fasilitas yang harus disediakan bagi pekerja-pekerja media. Tujuannya adalah pekerja media merasa nyaman dalam bekerja (Darmastuti, 2012). Peneliti mendapatkan data dilapangan bahwa PR PT. Pos Indonesia memberikan berbagai fasilitas kepada para media yang hadir dengan tujuan agar media merasa nyaman, fasilitas tersebut merupakan goodybag yang berisikan produk dari Pos Indonesia, biaya transport 
dan juga di sediakannya makanan untuk berbuka puasa. Kegiatan press tour diadakan di Kota Bandung dan pada saat bulan puasa, maka kegiatan press tour di mix dengan acara buka puasa bersama dengan pihak media. Bulan Ramadhan dijadikan sebagai moment silahturahmi agar tetap menjalin hubungan baik dengan para media. Sama halnya dengan hukum, dalam media juga diberlakukan kode etik. Dalam proses berkomunikasi dengan para media bersifat normatif, dimana PR PT. Pos Indonesia berpegang teguh pada norma atau aturan sesuai dengan kode etik jurnalis dan tentunya tidak melanggar kode etik jurnalis tersebut.

Strategi dalam menyediakan bahan informasi bagi para media yang hadir berhasil dilakukan oleh PR PT. Pos Indonesia, sehingga tercapainya tujuan dari kegiatan media relations. Adapun tujuan dari kegiatan media relations PT. Pos Indonesia yakni menjalin hubungan yang baik dengan media dan meningkatkan citra perusahaan dimata publik. Dari segala pemberitaan yang positif terhadap perusahaan akan membentuk citra PT. Pos Indonesia, untuk mencapai tujuan tersebut dibutuhkan media massa yang memberitakan segala informasi mengenai kegiatan perusahaan.

Menurut Philip Lesly, memberikan definisi media relations sebagai hubungan dengan media komunikasi untuk melakukan publisitas atau merespon kepentingan media terhadap kepentingan organisasi. (Saputra \&Nasrullah, 2011). Pernyataan diatas tidak jauh berbeda dengan yang diterapkan dalam Media Relations PT. Pos Indonesia, dimana media relations dijadikan sebagai jalur untuk mempermudah dalam melakukan publisitas, dengan adanya relasi yang tercipta maka dapat membuat publisitas semakin lebih mudah. PR PT. Pos Indonesia memerlukan adanya publisitas dalam mencapai khalayak sasarannya dan media pun membutuhkan informasi dalam membuat berita sehingga terciptanya kerja sama yang baik dalam penyediaan bahan informasi.

Menurut Frank Jefkins, seorang PR harus siap menyediakan dan memasok materimateri yang akurat dimana saja dan kapan saja. Dengan cara itulah seorang PR akan dinilai sebagai suatu sumber informasi yang akurat dan dapat dipercaya oleh wartawan. Berdasarkan fakta diatas, komunikasi timbal balik yang saling menguntungkan akan lebih mudah diciptakan dan dipelihara. Seorang PR dan wartawan dapat bekerja sama dalam mempersiapkan sebuah acara wawancara (Darmastuti, 2012).

Pernyataan diatas sesuai dengan data yang peneliti dapatkan di lapangan yaitu sebelum dilakukannya kegiatan press tour, pihak PR PT. Pos Indonesia mengadakan media briefing dan memberikan release dengan tujuan agar para media yang hadir tidak bingung dalam pembahasan dan tidak melebar dalam bertanya. Penyediaan informasi tersebut sebagai bentuk kerja sama yang dilakukan oleh PR PT. Pos Indonesia dengan para media. Dalam menyediakan bahan informasi. PR PT. Pos Indonesia menyampaikan informasi kepada media harus lugas, singkat dan jelas agar tidak adanya kesalahan dalam penyampaian informasi dan, PR PT. Pos Indonesia memilih tema yang memiliki news value yang tinggi agar mempunyai nilai berita yang menarik sehingga dipublikasikan oleh pihak media.

Menurut Marshall McLuhan yang menyatakan bahwa medium is the message atau media adalah pesan. Teori media (medium theory) adalah tentang bagaimana media dan proses komunikasi mempengaruhi persepsi manusia, perasaan, dan emosi. Diyakini bahwa media yang dipilih untuk menyampaikan pesan adalah sama pentingnya dari pesan itu sendiri. Dimana PR PT. Pos Indonesia menganggap dan meyakini bahwa dengan adanya proses komunikasi atau pesan yang telah dibuat dan disampaikan langsung oleh media dapat dengan mudah mempengaruhi persepsi masyarakat.

Dalam prespektif teori ini, bukan pesan yang mempengaruhi kesadaran kita tetapi media. Medialah yang lebih besar mempengaruhi bawah sadar kita. Media membentuk pesan, bukan sebaliknya. Tidak jauh berbeda dengan yang dilakukan oleh PR PT. Pos Indonesia, dimana PR PT. Pos Indonesia mengundang media dan adanya pesan yang disampaikan oleh PT. Pos Indonesia. Setiap media yang hadir di dalam kegiatan press tour tentunya mengolah kembali pesan yang disampaikan oleh pihak dari PT. Pos Indonedia dan membuat suatu pesan atau berita yang menarik dan pesan tersebut dapat dengan mudahnya mempengaruhi publik. 
Tujuan dari diadakannya kegiatan press tour adalah meningkatkan atau mendapatkan citra positif. Citra yang diinginkan oleh PR PT. Pos Indonesia adalah citra perusahaan. Sebelum diadakannya transformasi processing center berstandar internasional dan kegiatan press tour, banyak complain dari masyarakat mengenai sistem operasional PT. Pos Indonesia, dilakukannya perubahaan dalam standar internasioanl agar sistem operasional menjadi lebih baik dan berkurangnya jumlah complain dari masyarakat dan secara tidak langsung mempengaruhi citra PT. Pos Indonesia.

Menurut penelitian yang dilakukan oleh Torry Agus Prianto dan Titin Suhartini mengenai "Optimalisasi Peran Public Relations Di Museum Geologi Bandung", (2015), Peran PR bertugas memberikan citra instansi terhadap masyarakat. Peran PR sebagai penghubung dari perusahaan kepada media. contoh dengan banyaknya kerjasama baik dengan media televise, media cetak, ataupun media internet maka dapat membantu dalam menciptkan citra yang positif. Sebuah organisasi bisa berjalan dengan baik dipengaruhi oleh individu, individu tersebut adalah pimpinan dan individu lainnya adalah seorang $P R$, jika kedua unsur dalam organisasi tersebut saling mengisi dalam fungsinya tidak menutup kemungkinan krisis dalam organisasi akan berkurang dan citra semakin meningkat.

Berdasarkan pernyataan tersebut, sama halnya dengan apa yang dilakukan oleh PT. Pos Indonesia bahwa PR lah yang bertugas dalam menciptakan, memelihara dan meningkatkan citra dimata masyarakat. PR PT. Pos Indonesia menjalin hubungan dengan media massa yaitu media cetak, media elektronik dan juga media online. Dalam meningkatkan dan mendapatkan citra yang baik, Seorang PR memerlukan media massa untuk menyampaikan segala informasi mengenai perusahaan sehingga informasi tersebut sampai pada masyatakat. Didalam PT. Pos Indonesia, kinerja seorang PR sangat berpengaruh besar dalam perusahaan dan PR PT. Pos Indonesia percaya bahwa jika seorang PR menjalankan tugas dan fungsinya dengan baik maka citra perusahaan akan terus meningkat.

Dalam penilaian yang dilakukan oleh PR PT. Pos Indonesia, kegiatan press tour berjalan lancar dan sesuai harapan. Semua para media yang diundang pun hadir, dan tidak hanya itu para media pun mempublikasikan tentang kegiatan press tour yang bertemakan transformasi processing center berstandar internasional. Hal tersebut dikatakan oleh PR PT. Pos Indonesia, tujuan awal dari media relations PT. Pos Indonesia adalah menjalin hubungan yang baik dengan media dan meningkatkan citra perusahaan.

Menurut penelitian yang dilakukan oleh Muhammad Najih Farihanto, mengenai "Teman Tapi Mesra Humas dan wartawan", (2014), Salah satu bentuk evaluasi kegiatan strategi media dalah media mentoring. Media mentoring berfungsi untuk mengetahui apakah upaya yang dilakukan dalam hubungan media berjalan optimal, maka diperlukan evaluasi mengenai program yang sudah dilakukan. Keberhasilan program diukur dari publikasi yang optimal. Berdasarkan pantau berita bisa diketahui apakah program yang berjalan baik atau tidak".

Peneliti menganalisa bahwa setelah menyelenggarakan kegiatan media relations, seorang PR perlu melakukan media mentoring sebagai bentuk evaluasi kegiatan. Pernyataan tersebut sama halnya dengan yang dilakukan oleh PR PT. Pos Indonesia, setelah melakukan kegiatan media relations PR PT. Pos Indonesia melakukan media mentoring. Salah satunya kegiatan press tour yang diselenggarakan oleh PR PT. Pos Indonesia. media mentoring adalah PR PT. Pos Indonesia mengontrol apakah kegiatan yang sudah diselenggarakan tersebut di publikasikan oleh pihak media dan jika semua pihak media yang hadir di kegiatan melakukan publikasi dan akan berdampak pada citra perusahaan maka penilaian atau evaluasi yang dilakukan bernilai positif.

\section{PENUTUP}

Berdasarkan temuan pada penelitian di lapangan, dan analisa yang telah dilakukan, strategi media relations PT. Pos Indonesi melalui kegiatan press tour sangat baik sehingga tercapainya tujuan dari kegiatan press tour yaitu adanya publikasi dari setiap media yang hadir. Kegiatan press tour pun berjalan lancar sesuai dengan harapan, dampak yang terjadi adalah dampak positif, dimana jumlah complain dari masyarakat berkurang dratis dan tentunya sangat berpengaruh pada citra perusahaan. 
Strategi pelayanan kepada media adalah tepat waktu, memberikan kebebasan dalam meliput dan bertanya, menyediakan fasilitas yang dibutuhkan media pada saat kegiatan, kegiatan press tour yang bertepatan dengan bulan Ramadhan dijadikan sebagai moment silahturahmi dan staff PR PT. Pos Indonesia menggabungkan acara buka puasa bersama dengan para media. Strategi yang dilakukan dengan kerja sama yang baik dalam menyediakan bahan informasi sebelum diadakan-nya kegiatan press tour pihak PR PT. Pos Indonesia mengadakan media briefing terlebih dahulu dan memberikan release,dalam menyampaikan informasi harus lugas, singkat dan jelas.

Peneliti menyarankan dalam memberikan pelayanan kepada media sekaligus menjalin hubungan dengan media terutama dalam kegiatan press tour yang di lakukan PT. Pos Indonesia dapat diselenggarakan diluar kota, untuk mengajak para media menikmati objek wisata tetapi tetap ada konsep perusahaan yang ditonjolkan dan PR PT. Pos Indonesia tetap membangun dan menjalin relasi dengan pihak media agar tujuan perusahaan dapat tercapai sesuai dengan harapan.

\section{DAFTAR PUSTAKA}

Ardianto, Elvinaro. 2014. Handbook Of Public Relations. Bandung: Simbiosa Rekatam Media

Ardianto, Elvinaro. 2014. Metodologi Penelitian untuk PR Kuantitatif dan Kualitatif. Bandung: Simbiosa Rekatama Media

Ardianto, Elvinaro dan Q-Anees, Bambang. 2007. Filsafat Ilmu Komunikasi. Bandung: Simbimbiosa Rekatama Media

Darmastuti, Rini. 2012. Media Relations Konsep, Strategi dan Aplikasi. Yogyakarta: Andi

Farihanto, Muhammad Najih. 2014. Teman Tapi Mesra Humas Dan Wartawan. Jurnal
Komunikasi Profetik. Vol 7 No 2,Oktober 2014

Hidayat, Dasrun. 2014. Media Public Relations. Yogyakarta: Graha Ilmu

Moleong, Lexy. 2014. Metodologi Penelitian Kualitatif. Bandung: PT Remaja Rosdakarya

PakarKomunikasi.com. 2017. diakses pada tanggal 20 September 2017 pukul 11.00 WIB

(https://pakarkomunikasi.com/teorikomunikasi-massa)

Prianto, Torry Agus \& Titin Suhartini. 2015. Optimalisasi Peran Public Relations Di Museum Geologi Bandung. Jurnal Ilmu Komunikasi (J-IKA). ISSN: 2355-0287 53. Vol II. No.1 April 2015

Saputra, Wahidin \& Nasrullah, Rulli. 2011. Public Relations 2.0 Teori dan Praktik Public Relations di Era Cyber. Depok: Gramata Publishing

\section{BIODATA PENULIS}

Titin Suhartini, lahir di Bandung, 18 November 1956. Berhasil menyelesaikan studi program Strata-1 (S1) di Fakultas Ilmu Komunikasi Universitas Padjajaran pada tahun 1981 dan tamat dari program Magister (S2) jurusan Administrasi Pendidikan di Universitas Pendidikan Indonesia pada tahun 2002.

Kadek Mari Elvira, lahir di Singkawang, 19 Mei 1995. Pada 2013 mengenyam pendidikan program Strata-1 di Fakultas Ilmu Komunikasi Universitas BSI Bandung dengan mengambil Perminatan Public Relations. Pada 2017 memulai penelitian mengenai Strategi Media Relations PT. Pos Indonesia (Persero) Melalui Kegiatan Press Tour. Seminar yang telah diikuti diantaranya Seminar Protocoler dan Public Relations Career pada tahun 2015 dan tergabung dalam kepanitiaan event Simposium Komunikasi di tahun 2016. 